\title{
PENGARUH KUALITAS PELAYANAN TERHADAP TINGKAT KEPUASAN PELANGGAN PADA RUMAH MAKAN DI KABUPATEN NGAWI
}

\author{
Wulan Jayanti \\ Supri Wahyudi Utomo \\ Juli Murwani \\ Pendidikan Akuntansi IKIP PGRI MADIUN
}

\begin{abstract}
This study aims to examine the influence of service quality on customer satisfaction in the restaurant of Ngawi resident. Population in this research is customer of Ngawi resident restaurant. The number of samples considered representative and reflect the characteristics of the population were 50 respondents. The hypothesis tested in this study with the Product Moment Correlation Analysis Method and t test. The results of this study indicate there is a positive and significant effect of service quality on customer satisfaction in Ngawi resident restaurant.
\end{abstract}

Keywords: quality of service, customer satisfaction.

\begin{abstract}
Abstrak
Penelitian ini bertujuan menguji pengaruh kualitas pelayanan terhadap tingkat kepuasan pelanggan pada Rumah Makan di Kabupaten Ngawi. Populasi dalam penelitiian ini adalah pelanggan Rumah Makan di Kabupaten Ngawi. Jumlah sampel yang dianggap representatif dan mencerminkan ciri dari populasi adalah 50 responden. Hipotesis Dalam penelitian ini diuji dengan Metode Analisis Korelasi Product Moment dan uji t. Hasil penelitian ini menunjukkan terdapat pengaruh positif dan signifikan kualitas pelayanan terhadap kepuasan pelanggan pada Rumah Makan di Kabupaten Ngawi.
\end{abstract}

Kata Kunci : kualitas pelayanan, kepuasan pelanggan.

\section{PENDAHULUAN}

Tjiptono (2005) menyatakan bahwa salah satu cara yang dapat ditempuh untuk memahami harapan pelanggan dan kebutuhan pelanggan antara lain dengan melakukan pemantauan kepuasan pelanggan (misalnya dengan observasi, survei, ghost shooping, lost customer analysis).

Kepuasan atau ketidakpuasan pelanggan merupakan bagian dari pengalaman pelanggan terhadap suatu produk atau jasa yang ditawarkan. Berdasarkan pengalaman yang diperolehnya, pelanggan memiliki kecenderungan untuk membangun nilai-nilai tertentu. Nilai tersebut akan memberikan dampak bagi pelanggan untuk melakukan perbandingan terhadap kompetitor dari produk atau jasa yang pernah dirasakannya. Apabila sebuah perusahaan memberikan produk atau jasanya yang berkualitas baik, maka diharapkan mampu memenuhi harapan pelanggan dan akhirnya mampu memberikan nilai yang maksimal serta menciptakan kepuasan bagi pelanggan dibanding kompetitor-kompetitor yang ada.

Persaingan yang semakin tajam serta semakin kritisnya konsumen (pengguna) jasa pengiriman paket ini, merupakan faktor-faktor yang harus di perhatikan oleh 
perusahaan. Tidak hanya itu, perusahaan itu perlu mengubah orientasinya kepada orientasi pasar (konsumen) agar bisa bersaing. Berorientasi kepada pasar, berarti selalu memperhatikan dan mempertimbangkan selera konsumen (pelanggan) dalam memasarkan produknya.

Salah satu bentuk aktifitas yang dapat dilakukan perusahaan untuk memperoleh posisi bersaing dalam upaya pemasarannya itu adalah pelayanan, yang sering kali menjadi pertimbangan utama calon konsumen dalam memilih perusahaan jasa pengiriman. Dalam hal ini tentu saja pelayanan yang baik yang sesuai dengan kebutuhan dan keinginan-keinginan konsumennya, karena sebagaimana yang di kemukakan Philip Kotler (2002) bahwa, "para pelanggan tidak hanya menginginkan jasa pelayanan tertentu tetapi juga pelayanan dalam jumlah dan mutu yang memadai".

\section{KAJIAN TEORI DAN PENGEMBANGAN HIPOTESIS}

Definisi kualitas pelayanan terpusat pada pemenuhan kebutuhan dan keinginan konsumen. Menurut Wyckof yang di kutip Arief (2007), menyatakan bahwa "kualitas jasa adalah tingkat keunggulan yang di harapkan dan pengendalian atas tingkat keunggulan tersebut untuk memenuhi keinginan pelanggan."

Buchari (2005) menyebutkan bahwa kualitas dapat ditinjau dari sudut pandang produsen dan konsumen. Ditinjau dari pandangan produsen kualitas adalah produk yang dalam produksinya telah sesuai dengan spesifikasinya atau standar yang dibuat oleh perusahaan. Sedangkan dari sudut pandang konsumen kualitas adalah nilai atau kecocokan untuk digunakan. Dalam dasa warsa terakhir ini arti kualitas memang lebih banyak dilihat dari sudut pandang konsumen, karena perusahaan yang menyadari bahwa kelangsungan hidup perusahaan tergantung dari konsumen.

Muhtosim (2007) mengungkapkan bahwa kualitas pelayanan jasa merupakan tingkat keunggulan yang diharapkan dan pengendalian atas tingkat keunggulan tersebut untuk memenuhi keinginan pelanggan. Dengan kata lain ada dua faktor utama yang mempengaruhi kualitas jasa, yaitu expected service dan perceived service. Apabila jasa yang diterima atau dirasakan (perceived service) sesuai dengan harapan, maka kualitas jasa dipersepsikan baik dan memuaskan.

Pada dasarnya tujuan dari suatu bisnis adalah untuk menciptakan pelanggan yang merasa puas. Tjiptono (2005) menyatakan bahwa terciptanya kepuasan pelanggan dapat memberikan beberapa manfaat antara lain, hubungan yang harmonis antara perusahaan dan konsumennya, memberikan dasar yang baik bagi pembelian ulang dan terciptanya loyalitas pelanggan dan membentuk suatu rekomendasi dari mulut ke mulut (word-of-mouth) yang menguntungkan bagi perusahaan.

Menurut Engel, et al dalam Tjiptono (2005) mengungkapkan bahwa "kepuasan pelanggan merupakan evaluasi purna beli dimana alternatif yang dipilih sekurangkurangnya memberikan hasil (outcome) sama atau melampaui harapan pelanggan”. Kotler, dkk (2004) menandaskan bahwa "kepuasan pelanggan adalah tingkat perasaan seseorang setelah membandingkan kinerja yang ia rasakan dibandingkan dengan harapan".

Menurut Oliver dalam Sulistyo (2000) kepuasan keseluruhan ditetukan oleh ketidak sesuaian harapan yang merupakan perbandingan antara kinerja yang dirasakan dengan harapan. Dari definisi diatas dapat disimpulkan pada dasarnya kepuasan pelanggan merupakan kesesuaian antara harapan dengan kinerja yang diterima pelanggan. 
Menurut Tjiptono (2005) ada beberapa strategi yang dapat dipadukan untuk meraih dan meningkatkan kepuasan pelanggan, diantaranya: 1) Strategi pemasaran berupa relationship marketing. Strategi ini menjelaskan hubungan transaksi antara penyedia jasa dan pelanggan berkelanjutan, tidak berakhir setelah penjualan selesai. Maksudnya dijalin suatu kemitraaan jangka panjang dengan pelanggan secara terusmenerus sehingga diharapkan dapat menjadi bisnis ulangan. 2) Strategi superior customer service. Strategi ini berusaha menawarkan pelayanan yang lebih unggul dari pesaingnya. Untuk mewujudkannya dibutuhkan dana yang besar, kemampuan sumber daya manusia dan usaha yang gigih. Namun, perusahaan dengan pelayanan superior ini akan lebih meraih laba dan tingkat pertumbuhan yang lebih besar dari pada pesainggnya yang memberikan pelayanan interior. 3) Strategi uncanditional service guarentees atau extraordinary guarantees. Didalam strategi ini, untuk meningkatkan kepuasan pelanggan, perusahaan jasa dapat mengembangkan augmented service terhadap core service-nya, misalnya dengan merancang garansi tertentu atau dengan memberikan pelayanan purna jual yang baik. Strategi ini intinya komitmen untuk memberikan kepuasan kepada pelanggan yang pada gilirannya akan menjadi sumber dinamisme penyempurnaan kualitas jasa dan kinerja perusahaan, juga akan meningkatkan motivasi para karyawan untuk mencapai tingkat kinerja yang lebih baik dari pada sebelumnya. 4) Strategi penanganan keluhan yang efisien. Penanganan keluhan yang baik memberikan peluang untuk mengubah seseorang pelanggan yang tidak puas menjadi pelanggan yang puas. Ketidakpuasan bisa semakin besar bila pelanggan yang mengeluh merasa keluhannya tidak diselesaikan dengan baik. 5) Strategi peningkatan kinerja perusahaan. Strategi ini meliputi berbagai upaya seperti melakukan pemantauan dan pengukuran kepuasan secara berkesinambungan, memberikan pendidikan dan pelatihan yang menyangkut komunikasi. 6) Menerapkan quality function deployment. Quality function deployment (QFD) yaitu "praktek untuk merancang suatu proses sebagai tanggapan terhadap kebutuhan pelanggan”. QFD berusaha menterjemahkan apa yang dibutuhkan pelanggan dalam proses pengembangan produk sedini mungkin sehingga memungkinkan perusahaan memprioritaskan kebutuhan pelanggan, menemukan tanggapan inovatif terhadap kebutuhan tersebut dan memperbaiki proses hingga tercapai efektivitas maksimum.

\section{Penelitian Terdahulu}

Taylor (2002) menyatakan bahwa hubungan antara kualitas pelayanan dengan kepuasan pelanggan penting bagi perusahaan, dan peneliti, karena perusahaan (penyedia jasa) perlu mengetahui apakah tujuan perusahaan harus memiliki pelanggan yang puas dengan kinerja perusahaan atau memberikan "kualitas layanan yang dipersepsikan" pada tingkat maksimum.

Dengan demikian "kepuasan dapat mempengaruhi evaluasi pelanggan terhadap kualitas layanan. Pentingnya isu tersebut telah mendorong usaha untuk memperjelas hubungan antara kepuasan dan kualitas layanan". Hasil penelitian mereka menyimpulkan bahwa semakin tinggi tingkat kualitas layanan yang dipersepsikan, semakin besar kepuasan pelanggan. Hal ini disebabkan kualitas yang dipersepsikan merupakan kemampuan memutuskan tentang kesempurnaan atau superioritas entitas, atau juga merupakan suatu bentuk sikap, evaluasi secara menyeluruh dalam jangka panjang.

Tjiptono (2005) mengungkapkan bahwa kualitas memiliki hubungan yang erat dengan kepuasan pelanggan. Kualitas memberikan suatu dorongan kepada pelanggan untuk menjalin ikatan hubungan yang kuat dengan perusahaan. Dalam jangka panjang 
ikatan seperti ini memungkinkan perusahaan untuk memahami dengan seksama harapan pelanggan serta kebutuhan mereka. Dengan demikian, perusahaan dapat meningkatkan kepuasan pelanggan di mana perusahaan memaksimumkan pengalaman pelanggan yang menyenangkan dan meminimumkan pengalaman pelanggan yang kurang menyenangkan.

Rangkuti (2003) menjelaskan bahwa kepuasan pelanggan merupakan respons pelanggan terhadap ketidaksesuaian antara tingkat kepentingan sebelumnya dan kinerja aktual yang dirasakannya setelah pemakaian. Kepuasan pelanggan juga dipengaruhi oleh persepsi kualitas jasa, kualitas produk, harga dan faktorfaktor yang bersifat pribadi serta yang bersifat situasi sesaat. Salah satu faktor yang menentukan kepuasan pelanggan adalah persepsi pelanggan mengenai kualitas jasa yang berfokus pada lima dimensi kualitas jasa, yaitu: bukti fisik (tangibles), keandalan (reliability), daya tanggap (responsiveness), jaminan (assurance), empati (empathy).

Beberapa penelitian terdahulu yang dapat digunakan sebagai pembanding dalam mempelajari penelitian tentang pengaruh kualitas pelayanan terhadap kepuasan konsumen antara lain:

Griselda dan Panjaitan (2007), telah melakukan penelitian dengan judul: Analisis Pengaruh Kualitas Pelayanan Terhadap Kepuasan Konsumen Restoran Pulau Dua. Hasil penelitian yang ada dapat disimpulkan bahwa terdapat pengaruh, baik pengaruh langsung maupun pengaruh tidak langsung yang positif dan signifikan dari factor-faktor kualitas pelayanan terhadap kepuasan konsumen di Restoran Pulau Dua. Faktor yang memiliki pengaruh paling besar terhadap kepuasan konsumen restoran Pulau Dua adalah faktor empathy. Adapun indicator yang paling mewakili faktor empathy ini adalah X14 atau perhatian personal pelayan terhadap konsumen restoran Pulau Dua.

Lian Erlia Sari (2011), telah melakukan penelitian dengan judul: Analisis Pengaruh Kualitas Pelayanan Terhadap Jasa Restoran Terhadap Loyalitas Pelanggan Sakana Japanesse Restaurant di Delonix Hotel Karawang. Hasil penelitian menunjukkan bahwa kualitas pelayanan jasa mempunyai hubungan terhadap loyalitas pelanggan Sakana Japanesse Restaurant dan terdapat pengaruh positif rendah antara kualitas pelayanan jasa dengan loyalitas pelanggan Sakana Japanesse Restaurant. Adapun besarnya pengaruh kualitas pelayanan jasa terhadap loyalitas pelanggan dari hasil uji korelasi yang menunjukkan nilai 0,397. Sedangkan pengaruhnya dari perhitungan koefisien determinasi diperoleh nilai sebesar $15,76 \%$ artinya bahwa variable loyalitas pelanggan dipengaruhi atau dapat dijelaskan oleh variable kualitas pelayanan jasa. Sisanya sebesar $84,24 \%$ dipengaruhi oleh factor-faktor yang lain yang tidak diketahui dalam penelitian.

\section{Hipotesis}

Dengan mengacu pada beberapa telaah literartur di atas, maka melalui penelitian ini penulis akan mencoba melakukan penelitian tentang pengaruh kualitas pelayanan terhadap tingkat kepuasan pelanggan pada Rumah Makan Kabupaten Ngawi. Adapun hipotesis yang diajukan dalam penelitian ini adalah sebagai berikut.

H1 : Kualitas pelayanan berpengaruh positif dan signifikan terhadap tingkat kepuasan pelanggan di Rumah Makan di Kabupaten Ngawi.

HO : Kualitas pelayanan tidak berpengaruh positif dan signifikan terhadap tingkat kepuasan pelanggan di Rumah Makan di Kabupaten Ngawi. 


\section{METODE PENELITIAN}

\section{Identifikasi dan Pengukuran Variabel}

Variabel penelitian merupakan obyek penelitian suatu penelitian Variabel ini meliputi : variabel bebas dan variabel terikat.

1) Variabel bebas (Independent variabel). Adapun variabel bebas dalam penelitian ini adalah kualitas pelayanan di Rumah Makan Kabupaten Ngawi (X). Indikator yang dipakai untuk mengukur kualitas pelayanan adalah sebagai berikut : Bukti fisik (Tangiables), Kehandalan (Reliability), Daya Tanggap (Responsiveness), Jaminan (Assurance) dan Perhatian (Emphaty).

2) Variabel terikat (dependent variabel). Dalam penelitian ini variabel terikat adalah Kepuasan pelanggan (Y), yaitu preferensi tingkat kepuasan pelanggan dalam penggunaan jasa di Rumah Makan Kabupaten Ngawi.

\section{Populasi dan Pengambilan Sampel}

Populasi dalam penelitian ini adalah pelanggan Rumah Makan di Kabupaten Ngawi. Target karakteristik populasi yang ditetapkan adalah konsumen atau pelanggan yang telah menjadi pelanggan di Rumah Makan di Kabupaten Ngawi.

Sampel dalam penelitian ini yang dianggap representatif dan mencerminkan ciri dari populasi adalah 50 responden. Sampel dalam penelitian ini yang diambil adalah pelanggan Rumah Makan di Kabupaten Ngawi dari bulan November sampai bulan Desember (2 bulan).

Dalam penelitian ini, teknik pengambilan sampel yang digunakan adalah Purposive Sampling. Purposive sampling adalah teknik penentuan sampel dengan pertimbangan tertentu. Sesuai dengan namanya, sampel diambil dengan maksud atau tujuan tertentu. Seseorang atau sesuatu diambil sebagai sampel karena peneliti menganggap bahwa seseorang atau sesuatu tersebut memiliki informasi yang diperlukan bagi penelitiannya.

\section{Teknik Pengumpulan Data}

Dalam memperoleh data yang diperlukan dalam penelitian ini penulis menggunakan metode kuesioner, wawancara dan dokumentasi.

\section{Teknik Analisis Data}

Dalam menganalisa data-data dalam penelitian ini digunakan adalah metode analisis korelasi Product Moment. Analisis ini digunakan untuk mengetahui seberapa kuat hubungan kualitas pelayanan yang merupakan variabel independen berpengaruh terhadap kepuasan pelanggan yang merupakan variabel dependent adalah model analisis yang Korelasi Sederhana (Product Moment).

Agar kesimpulan dari suatu penelitian dapat diperoleh, maka perlu adanya suatu uji hipotesa yang telah dikembangkan. Uji hipotesa yang digunakan adalah Uji t.

Pengujian Uji t menggunakan uji dua sisi dengan tingkat signifikansi a $=5 \%$ (uji dilakukan 2 sisi karena untuk mengetahui ada atau tidaknya hubungan yang signifikan, jika 1 sisi digunakan untuk mengetahui hubungan lebih kecil atau lebih besar).

Tingkat signifikansi dalam mengambil keputusan untuk menolak hipotesa yang benar sebanyak-banyaknya 5\%. Langkah pertama adalah menentukan t hitung, langkah kedua adalah menentukan $t$ tabel dengan mencari pada tabel t pada $\alpha=5 \%: 2=2,5 \%$ (Uji 2 sisi) dengan derajat kebebasan (df) $=\mathrm{n}-2$ dan langkah ketiga adalah 
membandingkan nila $\mathrm{t}$ hitung dan $\mathrm{t}$ tabel. Kriteria pengujian hipotesis adalah sebagai berikut:

1) Jika t hitung > t tabel, maka hipotesis nol (H0) ditolak dan hipotesis kerja (H1) diterima.

2) Jika t hitung < t tabel, maka hipotesis nol (H0) diterima dan hipotesis kerja (H1) ditolak.

\section{HASIL DAN PEMBAHASAN \\ Statistik Deskriptif}

Gambaran dari masing-masing variabel dalam penelitian ini yaitu kualitas pelayanan (X) dan kepuasan pelanggan (Y) dapat dilakukan dengan analisis deskriptif persentase berikut ini:

1. Kualitas Pelayanan

Dalam rangka mengungkap kualitas pelayanan pelanggan di Rumah Makan di Kabupaten Ngawi, digunakan 10 butir pertanyaan dan masing-masing pertanyaan skornya antara 1 sampai 5.

Tabel 1

Kualitas Pelayanan Di Rumah Makan Di Kabupaten Ngawi Menurut Responden

\begin{tabular}{cccc}
\hline No & Kriteria & Frekuensi & Persentase \\
\hline 1. & Sangat Baik & 11 & 22 \\
2. & Baik & 25 & 50 \\
3. & Cukup Baik & 14 & 28 \\
4. & Tidak Baik & 0 & 0 \\
\hline & JUMLAH & 50 & 100
\end{tabular}

Sumber: Data Primer

Tabel di atas menunjukkan bahwa sebagian besar jawaban responden mengenai kualitas pelayanan di Rumah Makan di Kabupaten Ngawi berkategori baik dengan jumlah 25 orang (50\%), sedangkan sebagian kecil jawaban responden mengenai kualitas pelayanan di Rumah Makan di Kabupaten Ngawi berkategori tidak baik dengan jumlah 0 orang $(0 \%)$.

Lebih jelasnya data tentang kualitas pelayanan pelanggan Rumah Makan di Kabupaten Ngawi dapat disajikan secara grafis pada diagram batang berikut ini :

\section{Gambar 1}

Persentase Kualitas Pelayanan Pelanggan Rumah Makan di Kabupaten Ngawi

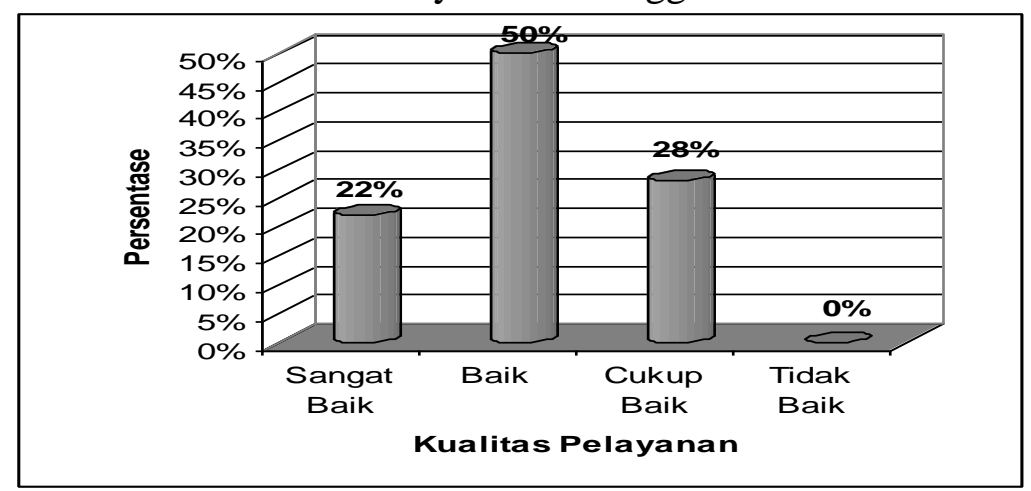


Berdasarkan gambar 6 di atas menunjukkan bahwa sebagian besar responden yaitu 50\% (25 orang) menyatakan kualitas pelayanan pada Rumah Makan di Kabupaten Ngawi baik, sedangkan selebihnya yaitu $28 \%$ (14 orang) menyatakan cukup baik, dan $22 \%$ (11 orang) menyatakan sangat baik dan tidak ada satupun responden yang menyatakan tidak baik.

\section{Kepuasan Pelanggan}

Dalam rangka mengungkap kepuasan pelanggan pada pelanggan di Rumah Makan di Kabupaten Ngawi, digunakan 10 butir pertanyaan dan masing-masing pertanyaan skornya antara 1 sampai 5 .

\section{Tabel 2}

Kepuasan Pelanggan Rumah Makan di Kabupaten Ngawi

\begin{tabular}{cccc}
\hline No & Kriteria & Frekuensi & Persentase \\
\hline 1. & Sangat puas & 10 & 20 \\
2. & Puas & 24 & 48 \\
3. & Cukup puas & 16 & 32 \\
4. & Tidak puas & 0 & 0 \\
\hline & Jumlah & 50 & 100
\end{tabular}

Sumber: Data Primer

Tabel di atas menunjukkan bahwa sebagian besar jawaban responden mengenai kepuasan pelanggan berkategori puas dengan jumlah 24 orang (48\%), sedangkan sebagian kecil jawaban responden mengenai kepuasan pelanggan terhadap Rumah Makan di Kabupaten Ngawi berkategori tidak puas dengan jumlah 0 orang (0\%).

Lebih jelasnya data tentang kepuasan pelanggan Rumah Makan di Kabupaten Ngawi dapat disajikan secara grafis pada diagram batang berikut ini :

\section{Gambar 2}

Persentase Kepuasan Pelanggan Rumah Makan di Kabupaten Ngawi

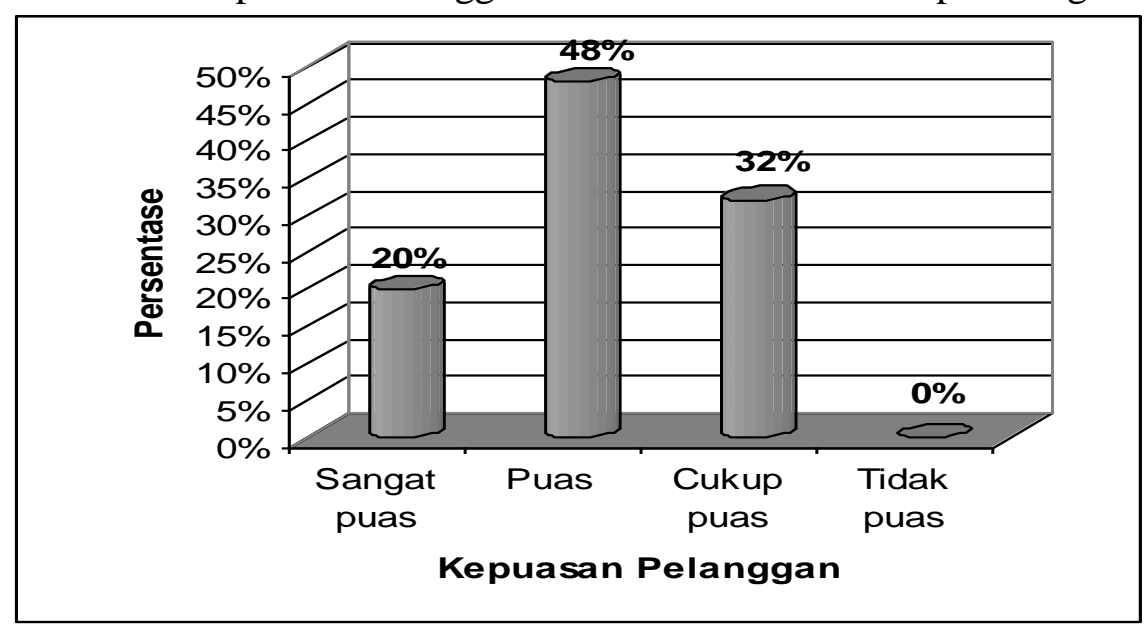

Berdasarkan gambar 7 di atas menunjukkan bahwa sebagian besar responden yaitu 48\% (24 orang) menyatakan puas dengan pelayanan Rumah Makan di Kabupaten Ngawi, sedangkan selebihnya yaitu 32\% (16 orang) menyatakan cukup puas, dan $20 \%$ 
(10 orang) menyatakan sangat puas dan tidak ada satupun responden yang menyatakan tidak puas terhadap pelayanan pelayanan Rumah Makan di Kabupaten Ngawi.

\section{Uji Hipotesis}

Guna pengujian secara statistik maka dirumuskan hipotesis nihil (Ho) "diduga pelayanan tidak berpengaruh positif dan signifikan terhadap tingkat kepuasan pelanggan di Rumah Makan di Kabupaten Ngawi” dan (H1) “diduga kualitas pelayanan berpengaruh positif dan signifikan terhadap tingkat kepuasan pelanggan di Rumah Makan di Kabupaten Ngawi”.

\section{Uji Pearson Correlation (Product Moment)}

Dalam rangka menguji hipotesis tersebut digunakan analisis korelasi sederhana (Product Moment). Tabel persiapan perhitungan koefisien korelasi adalah sebagai berikut.

Adapun rumus dan perhitungan yang digunakan dalam pengujian korelasi antara kualitas pelayanan terhadap kepuasan pelanggan ini adalah sebagai berikut.

$$
\begin{aligned}
\operatorname{rxy} & =\frac{n \sum x y-\left(\sum x\right)\left(\sum y\right)}{\sqrt{\left[n \sum x^{2}-\left(\sum x\right)^{2}\right]\left[n \sum y^{2}-\left(\sum y\right)^{2}\right]}} \\
& =\frac{50(40885)-(1090)(1095)}{50(40812)-(1090)^{2} 50(41359)-(1095)^{2}} \\
& =0,864
\end{aligned}
$$

Dimana

$\mathrm{X}=$ Kualitas pelayanan

$\mathrm{Y}=$ Kepuasan pelanggan

rxy $=$ Koefisien korelasi

Setelah dilakukan uji korelasi, maka didapatkan nilai koefisien korelasi atau rxy $=0,864$ yang artinya hubungan antara kualitas pelayanan terhadap kepuasan pelanggan memang sangat kuat karena nilai rxy mendekati 1. Hal ini menunjukkan bahwa terjadi hubungan yang sangat kuat antara kualitas pelayanan dengan kepuasan pelanggan di Rumah Makan di Kabupaten Ngawi. Sedangkan arah hubungan adalah positif karena nilai $r$ positif, berarti semakin tinggi kualitas pelayanan maka semakin tinggi pula kepuasan pelanggan.

\section{Uji Signifikansi (Uji t)}

Pengujian menggunakan uji dua sisi dengan tingkat signifikansi a $=5 \%$. Tingkat signifikansi dalam hal ini berarti kita mengambil risiko salah dalam mengambil keputusan untuk menolak hipotesa yang benar sebanyak-banyaknya 5\% (signifikansi $5 \%$ atau 0,05 adalah ukuran standar yang sering digunakan dalam penelitian).

Dalam menentukan $t$ hitung digunakan rumus sebagai berikut : 
$\mathrm{t}$ hitung $=\mathrm{r} \frac{\sqrt{n-2}}{1-r^{2}}$

Keterangan :

$\mathrm{r} \quad=$ Koefisien korelasi sederhana

$\mathrm{n} \quad=$ Jumlah data / responden

Jadi t hitung dapat dicari sebagai berikut :

$$
\begin{aligned}
\text { thitung } & =0.864 \cdot \frac{\sqrt{50-2}}{\sqrt{1-0,864}} \\
& =0.864 \cdot \frac{6 \cdot 928}{0,369} \\
& =16,22
\end{aligned}
$$

t tabel dicari pada tabel t yang dicari pada $\alpha=5 \%: 2=2,5 \%$ (uji 2 sisi) dengan df $=\mathrm{n}-2$ atau 50-2 = 48. Dengan pengujian 2 sisi (signifikansi $=0,025$ ) hasil yang diperoleh untuk $\mathrm{t}$ tabel adalah sebesar 2,011 (dilihat pada tabel t).

Kriteria pengujian adalah sebagai berikut :

$\mathrm{H} 0$ diterima jika $t$ hitung $<\mathrm{t}$ tabel

$\mathrm{H} 0$ ditolak jika $t$ hitung $>\mathrm{t}$ tabel

Hasil perbandingan $t$ hitung dengan $t$ tabel yaitu $t$ hitung $>t$ tabel $(16,22>2,011)$ dan $\mathrm{P}$ value $<0,05(0,000<0,05)$ maka $\mathrm{H} 0$ ditolak dan sebaliknya $\mathrm{H} 1$ diterima atau dengan kata lain terdapat hubungan atau pengaruh yang signifikan antara pelayanan terhadap kepuasan pelanggan pada Rumah Makan di Kabupaten Ngawi. Karena thitung yang benilai positif, maka berarti kualitas pelayanan berhubungan positif dan signifikan terhadap kepuasan pelanggan.

\section{Pembahasan}

Dari hasil analisis korelasi sederhana dapat diketahui bahwa kualitas pelayanan memiliki pengaruh yang nyata terhadap kepuasan pelanggan. Hal ini dapat dibuktikan dari hasil korelasi dimana $r=0,864$. Hasil korelasi tersebut menunjukkan bahwa kualitas pelayanan mempunyai hubungan sangat kuat terhadap kepuasan pelanggan. Hal ini berarti Rumah Makan di Kabupaten Ngawi telah melaksanakan kualitas pelayanan secara baik sehingga memberikan kesan di hati para pelanggan disamping memberikan hasil pelayanan yang memuaskan juga memberikan citra yang baik bagi pelanggan selama berada di Rumah Makan.

Seperti yang dikatakan Kotler bahwa meningkatkan kepuasan para pelanggan dapat terjadi apabila perusahaan memaksimumkan pengalaman pelanggan yang menyenangkan dan meminimumkan pengalaman pelanggan yang kurang menyenangkan. Usaha meningkatkan kualitas pelayanan dapat dimulai dari pemenuhan kebutuhan pelanggan dan berakhir pada presepsi pelanggan sebab meningkatkan nilai yang diterima pelanggan dalam tiap interaksinya dengan perusahaan, perusahaan akan lebih mungkin meningkatkan tingkat kepuasan, mengarah pada ketahanan pelanggan yang lebih tinggi. Ketika pelanggan bertahan karena merasa nyaman dengan nilai dan kenyamanan yang di dapat, akan lebih mungkin menjadi pelanggan yang loyal, meningkatkan intensitas pembelian dan merekomendasikan pada teman dan keluarga pelanggan tersebut.

Secara umum menunjukkan bahwa kualitas pelayanan merupakan faktor yang penting agar diperoleh tingkat kepuasan pelanggan yang tinggi. Dengan adanya kualitas pelayanan yang baik, maka minat pelanggan untuk menggunakan kembali jasa yang 
pernah digunakannya akan tumbuh, begitu juga dengan sebaliknya. Hal ini ditunjukkan dari hasil uji simultan dengan diperolehnya $r=0,864, \mathrm{t}$ hitung $>\mathrm{t}$ tabel $(16,22>2,011)$ dan $\mathrm{P}$ value $<0,05(0,000<0,05)$, yang berarti kualitas pelayanan secara signifikan berpengaruh terhadap kepuasan pelanggan atau berarti ada pengaruh yang signifikan antara kualitas pelayanan terhadap kepuasan pelanggan.

Bentuk pengaruh antara kualitas pelayanan terhadap kepuasan pelanggan adalah pengaruh positif yaitu semakin baik kualitas pelayanan maka semakin tinggi pula tingkat kepuasan pelanggan. Dengan demikian dapat dijelaskan bahwa jika variabel kualitas pelayanan pada Rumah Makan di Kabupaten Ngawi meningkat, maka akan diikuti dengan meningkatnya kepuasan pelanggan dan sebaliknya jika variabel kualitas pelayanan pada Rumah Makan di Kabupaten Ngawi menurun, maka akan diikuti dengan menurunnya pula kepuasan pelanggan.

\section{SIMPULAN DAN SARAN}

Berdasarkan hasil analisis, maka dapat ditarik kesimpulan sebagai berikut : terdapat pengaruh positif dan signifikan kualitas pelayanan terhadap kepuasan pelanggan Rumah Makan di Kabupaten Ngawi. Hal ini terbukti bahwa nilai koefisien korelasi (rxy) diperoleh sebesar 0,864, sedang hasil $\mathrm{t}$ diperoleh $\mathrm{t}$ hitung $>\mathrm{t}$ tabel $(16,22>2,011)$, sehingga H0 ditolak dan Ha diterima. Jadi hipotesis yang berbunyi "diduga kualitas pelayanan berpengaruh positif dan signifikan terhadap tingkat kepuasan pelanggan di Rumah Makan di Kabupaten Ngawi" terbukti dan diterima kebenarannya.

Saran-saran yang dapat diberikan penulis sesuai dengan hasil studi ini adalah agar sebaiknya Rumah Makan di Kabupaten Ngawi harus tetap menjaga kualitas pelayanan, mendengarkan keluhan pelanggan dengan ikhlas serta harus memiliki sikap responsif atau tanggap dengan kebutuhan pelanggan.

\section{DAFTAR PUSTAKA}

Alma Buchari, 2005. Manajemen Pemasaran dan Pemasaran Jasa, Edisi Revisi, Alfabeta, Bandung.

Arief Muhtosim, 2007. Pemasaran Jasa dan Kualitas Pelayanan, Bayu Publising, Malang.

Donald Cooper R dan C. William Emory, 1996. Metode Penelitian Bisnis. Jilid 1, Edisi Kelima. Erlangga, Jakarta.

Fandy Tjiptono, 2004. Pemasaran Jasa, Malang, Bayu Media. 2006. Manajemen Jasa, Andi Offset, Yogyakarta.

Freddy, Rangkuti, 2006. Teknik Mengukur dan Strategi Meningkatkan Kepuasan Pelanggan (Measuring Customer Satifaction), Penerbit PT Gramedia Pustaka Utama, Jakarta.

Lovelock, H. Christoper. Lauren K. Wright., 2005. Manajemen Pemasaran Jasa, Alih Bahasa Agus Widyantoro, PT.Indeks, Jakarta. 
Moureen Margaretha, 2004. "Studi Mengenai Loyalitas Pelanggan Pada Divisi Asuransi Kumpulan AJB Bumi Putera 1912”, Jurnal Sains Pemasaran Indonesia, Desember, Vol. III, No. 2.

Philip Kotler dan Gary Armstrong, 2001. Prinsip-prinsip Pemasaran, Jilid 1, Edisi Kedelapan, Erlangga, Jakarta.

Philip Kotler, 2002. Manajemen Pemasaran: Perencanaan, Implementasi, dan Pengendalian, Edisi Kesembilan, Jilid 1. PT. Prenhallindo, Jakarta.

Rambat Lupiyoadi, 2001. Manajemen Pemasaran Jasa, Penerbit Salemba Empat, Jakarta.

Sugiyono, 2007. Metode Penelitian Bisnis. Alfabeta: Bandung.

Suharsimi Arikunto, 2006. Prosedur Penelitian Suatu Pendekatan Praktek, Rineka Cipta: Jakarta.

Sumadi, 2001. Konsep dan Teknik Mengukur Kualitas Produk Jasa, FE UII, Yogyakarta.

Sumadi Suryabrata, 2001. Pengembangan Alat Ukur Psikologis, Penerbit ANDI, Yogyakarta.

Yazid, 1999. Pemasaran Jasa Konsep dan Implementasi, Ekonesia, Yogyakarta. 